Józef Kuffel

Kraków, Uniwersytet Jagielloński w Krakowie

\title{
Aspekty temporalne w Żywocie św. Kiryła Biełozierskiego
}

Temporal Aspects in The Life of St. Cyril of Beloozero

Abstract: The article discusses the basic references of The Life of St. Cyril of Beloozero by Pachomius Logotheta against the ambiguous language and cultural category of time. Five temporal aspects emerging in the studied hagiographic monument of Old Russian literature were selected and discussed: author's time, recipient's time, historical time, symbolic time, and eternity.

Keywords: hagiography, hesychasm, Moscovite Rus, Pachomius Logotheta, St. Cyril of Beloozero

\section{Wprowadzenie}

W niniejszym artykule podejmiemy próbę zasygnalizowania podstawowych odniesień Żywota św. Kiryła Biełozierskiego autorstwa Pachomiusza Logotety wobec wieloznacznej kategorii językowo-kulturowej, jaką jest czas. Najpierw wyznaczymy pięć aspektów temporalnych określających naszą analizę, a następnie każdy z nich pokrótce omówimy:

1. czas autorski,

2. czas odbiorcy,

3. czas historyczny,

4. czas symboliczny,

5. wieczność. 


\section{Czas autorski}

Czas autorski rozumiemy jako lata tworzenia utworu i perspektywę czasową hagiografa oraz osób, które bezpośrednio współuczestniczyły w powstaniu dzieła.

Pierwszy hagiograficzny utwór poświęcony założycielowi kiryło-biełozierskiego monasteru powstał z inicjatywy wielkiego księcia Wasyla II Ślepego (1415-1462) i metropolity moskiewskiego Teodozego (+1475). Zadanie napisania Żywota powierzyli Serbowi Pachomiuszowi Logotecie, który na krótko przed upadkiem Cesarstwa Wschodniego przybył na Ruś. Jest on cenionym autorem i redaktorem żywotów staroruskich świętych stosującym zasady Szkoły Wielkotyrnowskiej.

Hagiograf nie zalicza siebie do bezpośrednich świadków działalności tytułowego bohatera swojego utworu - był on hieromnichem należącym do kolejnego pokolenia, który przed 1438 r. przybył do Nowogrodu z Athosu'. Swoją opowieść o protoplaście Tebaidy Północy rozpoczyna od wyjaśnienia, w jaki sposób doszło do przezwyciężenia owego dystansu czasowo-przestrzennego:

Помыслитъ же кто, яко иныя ми земли суща и не вЂдяще опасно яже о святем. И въправду, не бо своима очима видъхъ того блаженнаго, ниже пакы что таковых бываемое, но, еще ми сущу далече, слышах о святьм, колика чюдеса творить Богъ его ради, - зьло удивихся. И сего ради, овогда повельнъ бывъ тогда самодръжцем великым княземъ Василием Василиевичем и благословениемъ же Феодосиа митрополита всеа Руси приити въ обитель святаго и тамо своими ушесы слышати бывшая и бывающая чюдеса от богоноснаго отца, тьмьже и великъ труд подъемъ далечяйшаго ради растоаниа мЂстом. Но понеже усердиемъ и пюбовию еже къ святому, якоже нькыим ужемъ длъгымъ, влеком, путь преидох и обитель святаго достигъ².

Gorliwość prawosławnego mnicha, do którego jeszcze poza granicami Rusi docierały wieści o Starcu i cudach z nim związanych, skłoniła go - przyszłego autora Żywota - do podjęcia trudów dalekiej i niebezpiecznej podróży z monasteru troicko-sergijewskiego do Kiriłowa. Mnich pisze również o znaczeniu miłości do Świętego, co mogłoby świadczyć o szerzącym się kulcie. Być może jednak należałoby pojęcie "miłość”, którą „jak swego rodzaju ogromnych rozmiarów powrozem

Na temat jego życia i działalności piśmienniczej zob. Г. Прохоров, Пахомий Серб (Логофет), Электронные публикации Института русской литературы (Пуикинского Дома) РАН, [online:] http://www.pushkinskijdom.ru/Default.aspx?tabid=3059 (10.11.2018).

Житие и подвизи преподобнаго отиа нашего игумена Кирилла, [w:] Преподобные Кирилл, Ферапонт и Мартиниан Белозерские, ред. Г. Прохоров, Санкт-Петербург 1994, s. 54. Wyróżnienie - tu i dalej autor artykułu (J.K.). 
był pociągany", odnieść do sensu, jaki się mu przydaje w dyskursie hezychastycznym. Miłość (cs. Любовь) jest to:

Boża energia jednocząca hipostazy Trójcy Swiętej, określana jako wzajemne, najgłębsze przenikanie się, całkowite oddawanie siebie drugiemu (gr. perichoresis) - aż po doświadczenie wzajemnej tożsa mości pomiędzy Nimi, przy zachowaniu własnej identyczności. Przestrzenią przyswajania niestworzonego daru Miłości Bożej jest modlitwa. Przyjmowany, konstytuuje on nowy, osobowy sposób istnienia oparty na synergii Bożej miłości i ludzkiej. Wyrazem przyswojenia tego daru staje się miłość do brata, która pomimo swej stworzoności jest zgodna z niestworzoną energią Bożą ${ }^{3}$.

Ta właśnie Miłość, której źródło jest transcendentne wobec człowieka (według określenia z traktatu św. Dionizego Areopagity jedno z „imion Bożych"4), stanowi cel życia chrześcijanina i moc sprawczą w przemianie prowadzącej do świętości przebóstwienia (cs. обожение). Ona, jak widać, działa również w hagiografie, który w swej aktywności twórczej wchodzi $z$ nią w synergię.

Zamysł utworu hagiograficznego nowego typu, poświęconego współczesnemu świętemu pochodzącemu z Moskwy, mógł wynikać nie tylko z pobudek wdzięczności wielkiego księcia wobec Kiryłowej Braci za poparcie w okresie smuty Dymitra Szemiaki. Współinicjator powstania Żywota - Teodozy - był pierwszym metropolitą noszącym tytuł "moskiewskiego i wszech Rusi” (dotychczas tytułowano ich "kijowskimi”) ${ }^{5}$. Został on wybrany z woli wielkiego księcia i z błogosławieństwem swego poprzednika metropolity Jony przez sobór wschodnioruskich biskupów, a więc w sposób niekanoniczny z punktu widzenia patriarchatu greckiego ${ }^{6}$. Być może w intencji moskiewskich decydentów Kirył Biełozierski miał pełnić rolę symbolu prawdziwej, samodzielnej Cerkwi ruskiej, zdolnej rodzić świętych nie mniejszego formatu niż ci, którymi szczyciły się pradawne patriarchaty.

Matryca Pojęciowa Hezychazmu: hasło “Любовь", [w:] J. Kuffel, Hezychazm Rusi Moskiewskiej. Metoda interpretacji na podstawie wybranych zabytków literatury przekładowej $i$ oryginalnej, Kraków 2013, s. 63.

4 Zob. Pseudo-Dionizy Areopagita, Imiona Boskie. Teologia mistyczna. Listy, przeł. M. Dzielska, przedmowa T. Stępień, Kraków 1997.

Por. А. Карташев, Московский период: Арx. Феодосий (1461-1464 22.), [w:] idem, История Русской Церкви,[online:] https://azbyka.ru/otechnik/Anton_Kartashev/ocherki-po-istorii-russkoj-tserkvi-tom-1/11_4_1 (5.11.2018).

6 Dokładniej o okolicznościach wyboru metropolity Teodozego (Bywalcewa) - zob. В. Лypьe, Русское православие между Киевом и Москвой, Москва 2009, s. 71 -74. Autor utrzymuje, że nie ma dowodów na to, iż używano w odniesieniu do niego tytułu „Metropolita Moskwy i wszech Rusi”. Według niego Teodozy, podobnie jak jego poprzednik, zachował tytuł „metropolity Kijowa i wszech Rusi", a dopiero w XVI w. w oficjalnym tytułowaniu Kijów zastąpiono Moskwą. 
Pachomiusz, przebywając w ziemi biełozierskiej (1462-1463), nie tylko rozmawiał z mnichami, którzy znali osobiście założyciela wspólnoty, ale ponadto kierował warsztatem piśmienniczym monasteru, przekazując swoje umiejętności kontynuatorom tradycji św. Kiryła. Autor Żywota przywołuje z imienia ihumena Kasjana i starca Martyniana spośród grona pozostających jeszcze przy życiu uczniów, których spotkał w ziemi biełozierskiej:

Видъхомъ тамо настоателя тоя обители Касиана именем, достойна игуменом глаголатися, мужа, от многых лђт въ трудђх постничьскых състарђвшася. Сей убо множае начат ми глаголати нъчто о святем написати, бяше бо велию в ру имъя къ блаженному Кирилу, иже самовидець бяше блаженаго и многым его чюдесем сказатель ми истинный бысть. Обрьтох же тамо и иных многыхъ от ученикъ его. Яко столпи непокольбимии въистинну пребывающе, иже многа льта живше съ святым, въ всем ревнующе учителю своему, якоже научени бывше отъ него. И ничтоже предъла отечьскаго не разорися от них, но тако пребывающе бяху благодатию Христовою въ постьх и въ молитвах и бдъниихъ, безмолствующе: якоже видяше отца творяща сиа, тщахуся собою и дылы исправити, якоже бы рещи: “Сии - род ищущих Господа и ищущих лице Бога Иаковля». Паче подобно глаголати: “Сии - древеса доброплодна, ихъже насади Господь Богъ нашь". И бяше видъти образъ тъхъ житиа доволенъ и кромЂ писаниа къ извъщению тђх добродътелей.

Ихже азъ въпросивъ о святьм, начаша бесьдовати ко мнђ о житии святаго и о чюдесъх, бывающих от него: овъ - сиа, ини же - подобна тьм. И на многы различны части глаголанна бъ святаго дъйствиа. Елма же азъ слышавъ от самовидца того житиа паче же достов ьрн ъйшая отъ самого того ученика Мартиниана именем $[. . .]^{7}$.

Jak mogliśmy się przekonać, Pachomiusz zaświadcza, że dane mu było własnymi oczami oglądać uczniów wiernie zachowujących praktykę swego Starca, i w oparciu o ich wizerunki zrekonstruował jego realny, a nie tylko symboliczny (w znaczeniu ikony) obraz. Użyte sformułowanie "kolumny nieporuszone” (cs. яко столпи непоколюбими въистину пребывающе) sugeruje niezmienność - stałość - nieprzemijalność, czyli niepodleganie determinacjom czasowym owego żywego wizerunku. 


\section{Czas odbiorcy}

Ten aspekt dotyczy perspektywy, z której widziały świętego pokolenia czcicieli oraz czytelników jego Żywota. Nie będziemy dłużej zatrzymywać się na tym zagadnieniu, zwrócimy tylko uwagę na fakt, że w pierwszym pokoleniu jest on tożsamy z czasem autorskim, a w kolejnych coraz bardziej się od niego oddala - aż do dnia dzisiejszego.

W jego ramach można również rozpatrywać epizod powstawania niniejszego artykułu - czyli kolejne odczytanie Żywota z perspektywy „tu i teraz” współczesnego czytelnika.

\section{Czas historyczny}

Mamy na myśli okres, którego dotyczą opisane postaci i wydarzenia, w tym wypadku widziany zgodnie ze średniowieczną, prawosławną historiozofią. W literaturze staroruskiej historyczne dzieje Rusi przedstawia się w łańcuchu dziejów kolejnych ludów przyjmujących chrześcijaństwo, ze szczególnym akcentem na bizantyńsko-słowiańską wspólnotę religijno-kulturalną. Postać św. Kiryła wiąże się z późniejszym etapem owych dziejów, zapoczątkowanym w XIV w., w okresie niewoli mongolskiej, kiedy pod egidą Moskwy następuje jednoczenie ziem ruskich.

Od samego początku swej monastycznej drogi Kirył obracał się w środowisku uczniów św. Sergiusza z Radoneża uznawanego za duchowego Przewodnika Rusi Moskiewskiej. Nie przypadkiem Kirył został mnichem moskiewskiego monasteru Simona, gdzie ihumenem był Teodor, bratanek św. Sergiusza. Jak czytamy w Pachomiuszowym żywocie - archimandryta troicki utrzymywał zażyłe relacje $z$ obydwoma mnichami ${ }^{8}$. Po wyborze archimandryty Teodora na arcybiskupa rostowskiego (1386 r.) to Kirył został jego następcą. Sprawowanie funkcji przeszkadzało jednak pełnemu odosobnieniu i naruszało milczenie (cs. того безмолвие npeceua $a y^{9}$ ). Z tego powodu wbrew prośbom braci postanowił z niej zrezygnować i ukrył się w Starym Simonowie. Nadzieje na to, że nie będąc ihumenem, uzyska warunki do praktykowania milczenia, najwidoczniej jednak zawiodły. Dlatego pustelnik zaczyna myśleć o jeszcze większym oddaleniu się od świata.

Mniej więcej w sześćdziesiątym roku życia - wiedziony pragnieniem hezychii - Kirył wraz z simonowskim ekonomem Fierapontem opuszczają potajemnie 
Moskwę, udając się w odludne lasy ziemi wołogodzkiej. W ten oto sposób nad malowniczymi jeziorami Biełozierza - w odległości mniej więcej 18 kilometrów od siebie - powstaną dwa słynne centra monastyczne ${ }^{10}$.

\section{Czas symboliczny}

Umownie ów aspekt temporalny będziemy nazywali czasem "realnym" - jest on zaszyfrowany w substracie hagiograficznym stosownie do funkcji i właściwości gatunku. Spróbujemy uzasadnić tezę, zgodnie z którą w Żywocie przekazano świadectwo o epoce kształtowania się moskiewskiej formacji państwowej. W intencji jej elit etos kulturalno-religijny zjednoczonej Rusi miał się opierać na idei oraz praktyce modlitewno-ascetycznej hezychazmu kultywowanej w środowiskach monastycznych.

Hagiograf celowo zaakcentował w działalności protoplasty Tebaidy Północy wątek hezychastyczny. Sam Pachomiusz związany był z tym kierunkiem duchowym zarówno przez pobyt na Athosie, jak i kraj swego pochodzenia. Wszak po upadku drugiego Królestwa Bułgarskiego to właśnie Serbia stanie się na pewien czas kontynuatorką Szkoły Wielkotyrnowskiej".

Pojawienie się hezychastów na Rusi związane było z rozkwitem literatury bizantyńskiej eksponującej kierunek mistyczno-ascetyczny prawosławia - w związku ze zwycięstwem palamizmu na soborach w Konstantynopolu około połowy XIV w. Dzięki patriarchom palamitom - uczniom autora Triad oraz Grzegorza Synaity - a także dokonaniom bułgarskich i serbskich knizników ${ }^{12}$ do wschodnich Słowian docierają przekłady pism Świętych Ojców, zarówno wcześniejszych, jak i im współczesnych.

Nurt hezychazmu w kulturze Rusi przełomu XIV i XV w. jest obecny głównie w literaturze przekładowej, liturgii oraz ikonografii. W pierwszych dziesięcioleciach XV w. ujawnia się również w utworach rodzimych hagiografów stosujących stylistykę "splatania słów” (cs. плетение словеc) wypracowaną w środowisku bułgarskiego patriarchy Eutymiusza. W nowej hagiografii literatura staroruska dorównała twórczości pobratymców z Południa wspaniałymi żywotami św. Sergiusza z Radoneża i Stefana Permskiego - autorstwa Epifaniusza Mądrego.

10 Рог. Г. Прохоров, Преподобный Кирилл Белозерский - деятель православного возрождения, [w:] Преподобные Кирилл, Ферапонт..., s. 22-23.

1 Por. Р. Пиккио, История древнерусской литературы, Москва 2002, s. 133.

12 Zob. ibidem, s. 129-141. 
Zasługą św. Sergiusza i pierwszego pokolenia jego uczniów było bezprecedensowe ożywienie zainteresowania księgami na Rusi. Wiodąca prym na przełomie XIV i XV w. kolekcja manuskryptów monasteru troicko-sergijewskiego ${ }^{13}$ stanie się wzorcem dla licznych, nowo zakładanych wspólnot monastycznych, pełniących rolę centrów piśmiennictwa, edukacji i nauki ${ }^{14}$.

Pierwszy ihumen kiriło-biełozierski szczególną wagę przydawał działalności piśmienniczej, angażując $w$ nią całą wspólnotę. Wśród zachowanych dwudziestu sześciu manuskryptów powstałych w kręgu św. Kiryła wyjątkowe znaczenie - ze względu na hezychastyczny charakter - mają trzy egzemplarze Drabiny rajskiej. Spomiędzy dzieł zredagowanych przez samego Starca najważniejszy jest zabytek przechowywany w Oddziale Rękopisów Rosyjskiej Biblioteki Narodowej w Sankt Petersburgu, opublikowany pod znamienną nazwą Encyklopedia staroruskiego ihumena $X I V-X V w .{ }^{15}$ Ó 862-stronicowy manuskrypt układa się w integralną calość uzasadnioną potrzebami hezychazmu.

Własna twórczość oraz krąg lektur stanowią najlepsze źródło danych potwierdzających tezę o przynależności biełozierskiego kniżnika do nurtu duchowego bizantyńsko-słowiańskiego hezychazmu. Potwierdzone to zostało jednoznacznie w jego pierwszym $\dot{Z}$ ywocie powstałym w oparciu o świadectwa współczesnych mu przedstawicieli tejże Tradycji.

\section{Wieczność}

Zgodnie z prawosławną wizją pojęcie „wieczność" wyznacza perspektywę wyniesienia człowieka do Bożego mo du su is t n ie n ia, tj. nowy stan ludzkiej natury nieograniczonej uwarunkowaniami czasowymi, określany w literaturze patrystycznej mianem przebóstwienia (ros. обожениe). W tej ostatniej - ostatecznej - perspektywie spotykają się wszystkie aspekty temporalne związane z Żywotem św. Kiryła Biełozierskiego.

Na uwagę zasługuje to, że zaproponowane ujęcia kategorii czasu są ze sobą powiązane, przenikają się wzajemnie i częstokroć nie sposób jest je precyzyjnie roz-

13 Por. Преподобные Нил Сорский и Иннокентий Комельский, Сочинения, изд. подг. Г. Прохоров, Санкт-Петербург 2005, s. 8.

14 Рог. В. Иконников, Опыт исследования о культурном значении Византии ө русской истории, Киев 1869, s. 94.

is Szczegółowo na temat rękopisów kręgu św. Kiryła oraz zawartości wspomnianego zbioru - zob. Предисловие, [w:] Г. Прохоров, Энциклопедия русского игумена XIV-XV вв. Сборник преподобного Кирилла Белозерского. Отв. ред. Г. Прохоров, Санкт-Петербург 2003, s. 9-13. 
graniczyć. Możemy zauważyć ponadto ich hierarchiczność, co w sposób oczywisty wpływa na wymowę utworu. Ustalenie owej hierarchii ma zresztą decydujące znaczenie dla interpretacji $\dot{Z} y$ wota. W intencji hagiografa ostatni aspekt naszego wywodu wysuwa się na pierwszy plan. Wieczność, która stanowi podstawową kategorię chrześcijańską, w tym wypadku ukazywana jest jednak przez pryzmat hermeneutyki hezychazmu.

Najważniejszy termin - „hezychia” (cs. безмолвие) - owego kierunku mistyczno-ascetycznego, który rozwijał się w okresie pomiędzy IV i XV w. na terenie Bizancjum, a potem również wśród prawosławnych Słowian, stanowiąc rdzeń prawosławnej antropologii, w utworze Pachomiusza również pełni decydującą rolę. Słowo to możemy tłumaczyć jako 'milczenie', 'wyciszenie', ale też 'uspokojenie' rozumiane jako głęboki pokój ogarniający wszystkie psychosomatyczne aspekty osoby ludzkiej.

Jak czytaliśmy powyżej - we fragmencie początkowym Żywota - uczniowie naśladowcy Starca: „[...] niczego nie zmienili w regułach Swiętych Ojców, ale łaską Chrystusową [prowadzeni] dni spędzają w postach, modlitwach i czuwaniach, praktykując hezychię (cs. безмолвствуя) jako widzieli czynił to ich ojciec, tak też sami starają się wypełniać [...]"16.

$\mathrm{W}$ simonowskim monasterze - jednym $\mathrm{z}$ głównych centrów moskiewskiego hezychazmu, którym kierował archimadryta Teodor, bratanek i uczeń św. Sergiusza z Radoneża - spełniło się pragnienie Koźmy (przyszłego ihumena Kiryła) bycia mnichem. Po przejściu okresu prób w piekarni i kuchni, pod kierunkiem hezychasty starca Michała, zapragnął odizolować się w celi, jak podkreśla hagiograf: „не покоя ради, но яко да от безмолвиа болше умиление стяжати в келии”. Później zaś - wbrew naleganiom wspólnoty - rezygnuje $z$ funkcji archimandryty, którą objął po chirotonii Teodora na arcybiskupa rostowskiego, a motywację jego określa to samo dążenie do hezychii:

Мнози отвсюду князи и велможи прихождаху к нему ползы ради и того безмолвие пресъцаху, тъмже помысли оставити начальство и в келии безмолъствовати, еже и сътвори, оставль бо настоательство и в келию свою отиде. Братиамъ много молившим его же не отлагати настоательства санъ, но тъй никакоже послушаше их и тако прочее въ тризнище подвига болшаго вшед - безмолъствовати начятъ, никоеже ими попечение от внбшних ${ }^{17}$.

Potem, nie będąc już archimandrytą, opuszcza Nowe Simonowo, aby z dala od rozproszeń cenobitycznej wspólnoty i ludzkiej zawiści zajmować się tym, co uważa za cel życia monastycznego: „Отходит оттуду въ древний монастырь Рожества

16 Житие и подвизи..., s. 54 (przel. J.K.).

17 Ibidem, s. 70. 
Пречистыя и тамо безмолъствуеть бяше" ${ }^{18}$. Tam właśnie, w samotnej celi, pośród ruin monasteru simonowskiego, którym wcześniej kierował, podczas modlitwy o północy doznaje cudownego objawienia, w którym Bogurodzica wskazuje mu miejsce realizacji jego pragnień. Ograniczenia czasowo-przestrzenne w momencie mistycznego widzenia przestają mieć znaczenie:

Бяше же обычай святаго по многом своем правиль и славословениих въ глубокий вечеръ, егда хотяше нъчто мало сна вкусити, и абие посльди Акафисто Пречистыя пояше. Тако бо всегда творяше. Случи же ся ему въ едину от нощий молящуся, вечеру глубоку сущу, и Акафисто Пречистьй по обычею поющу пред образом ея, и егда доиде мъста, писаннаго въ икосъ, “Странно рожество видяще, устранимся мира и умъ на небо преложимъ", абие слышит гласъ глаголющь: «Кирииле, изыде отсюду и иди на Бълоезеро, тамо бо уготовах ти мЂсто, в немже можеши спастися». И абие съ гласом онђм свът велий явися тогда. Отворив же оконце кЂлии, видит свђт, сиающь къ полунощнымъ странамъ БЂлаго озера. И гласом онъм, яко перстом, показаше мЂсто то, идђже и нынъ монастырь стоит. Тъмже святый Кирииль от гласа оного и видъниа радости многы исполнився. Разум 60 отъ самого того гласа святаго и видъниа, яко не презрь Пречистая прошениа его, и всю нощь бяше дивяся бывшему съ гласом видьнию, и не бяше ему она нощь яко нощь, но яко день пресвьтлый ${ }^{19}$.

Wkrótce po tym widzeniu - po powrocie z ziemi wołogodzkiej simonowskiego ekonoma, starca Fieraponta - Kirył zadaje pytanie: „есть ли мъста тамо на Бъльезере, идъже мощно безмолъствовати иноку?" 20 . Po udzieleniu odpowiedzi twierdzącej dwaj starcy wspólnie podejmują decyzję o opuszczeniu Moskwy.

Po przybyciu na miejsce, gdzie dziś wznosi się monaster kiriło-biełozierski, jego założyciel wypowiada słowa, które możemy uznać za kulminację ziemskich poszukiwań Starca, a zarazem centralny fragment utworu:

По обхождении же многых мЂстъ, посльди приидоша на мъсто, идъже нынъ манастырь стоит. И абие позна святый прежде указанное ему мЂсто и взъпюби его зђло. И сътворивъ молитву, и рече: „Се покой мой въ вькы вђка. Здъ вселюся, яко Пречистая изволи его. Благословенъ Господь Богь отнынъ и до въка, иже услыша моление мое". И тако крестъ въдрузивше на мъсть, и благодарный канонъ отпьвше в похвалу Пречистые Владычице нашея Богородици и Приснодъвыа Марии ${ }^{21}$.

It Ibidem, s. 72.

is Ibidem.

20 Ibidem.

2 Ibidem. 
W sformułowaniu „Oto pokój mój na wieki wieków. Tutaj zamieszkam” - autor Żywota ustami Świętego wyraził głęboki sens hezychii, określając jednocześnie uniwersalny cel dążeń wyznawców prawosławia. Jest to ów pokój obiecywany w Ewangelii przez Chrystusa, którego świat dać nie może ${ }^{22}$. Nie podlega on żadnym ograniczeniom czasowym, tzn. nigdy nie przemija ani nie słabnie, ale ogarnia ludzkie serce niewysłowioną pełnią i poczuciem bezpieczeńst wa. W sensie znaczeniowym, dla prawosławnej antropologii, jest to termin bliskoznaczny dla takich słów jak: przebóstwienie, mądrość scalająca (gr. sophrone, cs. целомудрие) oraz zbawienie (gr. soteria, cs. спасениe). Hezychasta pragnie osiągnąć ów nowy, przekraczający to, co znamy, stan istnienia - temu poświęca wszystkie swoje siły - jest on wynikiem realnej w sensie ontologicznym przemiany ludzkiej natury. W ujęciu antropologii synergijnej, dla której m.in. hagiografia stanowi materiał badawczy, jest to przekroczenie granicy ontologicznej. Wówczas prawa obecnej egzystencji, w której przejawiają się skutki grzechu, przestają determinować myśli, uczucia, postępowanie i całe nasze doczesne życie. Swięty to nowy człowiek, przemieniający się w procesie duchowym, którego początek wyznacza chrzest, a kresem jest doskonałe upodobnienie ${ }^{23}$, tj. utożsamienie z Chrystusem. Przez zjednoczenie z Nim zostaje przekroczona granica wieczności, a nieublagane czas i śmierć zostają przezwyciężone - przestają być rozpatrywane jako ograniczenie i przekleństwo, a przeistaczają się w sprzymierzeńców $w$ realizacji ostatecznego celu, którym jest wkroczenie w wymiar życia Bożego.

\section{Bibliografia}

Kuffel J., Hezychazm Rusi Moskiewskiej. Metoda interpretacji na podstawie wybranych zabytków literatury przekładowej i oryginalnej, Kraków 2013.

Pismo Swięte Starego i Nowego Testamentu, Biblia Tysiąclecia Online, Poznań 2003, [online:] http://www.biblia.deon.pl/.

Pseudo-Dionizy Areopagita, Imiona Boskie. Teologia mistyczna. Listy, przeł. M. Dzielska, przedmowa T. Stępień, Kraków 1997.

Житие и подвизи преподобнаго отиа нашего игумена Кирилла, [w:] Преподобные Кирилл, Ферапонт и Мартиниан Белозерские, ред. Г. Прохоров, Санкт-Петербург 1994.

22 Por. „Pokój zostawiam wam, pokój mój daję wam. Nie tak jak daje świat, Ja wam daję. Niech się nie trwoży serce wasze ani się lęka!" (J 14, 27, Pismo Święte Starego i Nowego Testamentu, Biblia Tysiąclecia Online, Poznań 2003, [online:] http://www.biblia.deon.pl/ (30.10.2018).

23 Por. „święty mnich", cs. nреподобный - pojęcie to wyraża nadzwyczajne, doskonale podobieństwo do Boga. 
Иконников В., Опыт исследования о культурном значении Византии в русской истории, Киев 1869.

Карташев А., Московский период: Арх. Феодосий (1461-1464 22.), [w:] tegoż, История Русской Церкви, [online:] Православная энциклопедия, “Азбука веры", https://azby ka.ru/otechnik/Anton_Kartashev/ocherki-po-istorii-russkoj-tserkvi-tom-1/11_4_1.

Лурье В., Русские православные между Киевом и Москвой, Москва 2009.

Преподобные Нил Сорский и Иннокентий Комельский, Сочинения, изд. подг. Г. Прохоров, Санкт-Петербург 2005.

Пиккио Р., История древнерусской литературы, Москва 2002.

Прохоров Г., Пахомий Серб (Логофет), Электронные публикации Института русской литературы (Пушкинского Дома) РАН, [online:] http://www.pushkinskijdom. ru/Default.aspx?tabid=3059.

Прохоров Г., Энииклопедия русского игумена XIV-XV вв. Сборник преподобного Кирилла Белозерского. Отв. ред. Г. Прохоров, Санкт-Петербург 2003.

\section{Informacja o Autorze}

Dr hab. Józef Kuffel, prof. UJ (Юзеф Куффель) - pracownik Katedry Średniowiecznej i Nowożytnej Literatury Rosyjskiej Instytutu Filologii Wschodniosłowiańskiej Wydziału Filologicznego Uniwersytetu Jagiellońskiego.

e-mail: jozef.kuffel@uj.edu.pl

https://orcid.org/0000-0001-8223-6209 